\title{
Article \\ Development of Real-Time and Conventional PCR Assays for Identifying a Newly Named Species of Root-Lesion Nematode (Pratylenchus dakotaensis) on Soybean
}

\author{
Intiaz Amin Chowdhury (1) and Guiping Yan * \\ Department of Plant Pathology, North Dakota State University, Fargo, ND 58108, USA; \\ intiaz.chowdhury@ndsu.edu \\ * Correspondence: guiping.yan@ndsu.edu
}

Citation: Chowdhury, I.A.; Yan, G. Development of Real-Time and

Conventional PCR Assays for

Identifying a Newly Named Species of Root-Lesion Nematode

(Pratylenchus dakotaensis) on Soybean. Int. J. Mol. Sci. 2021, 22, 5872.

https://doi.org/10.3390/ijms22115872

Academic Editor: Yong-Gu Cho

Received: 6 May 2021

Accepted: 26 May 2021

Published: 30 May 2021

Publisher's Note: MDPI stays neutral with regard to jurisdictional claims in published maps and institutional affiliations.

Copyright: (c) 2021 by the authors. Licensee MDPI, Basel, Switzerland. This article is an open access article distributed under the terms and conditions of the Creative Commons Attribution (CC BY) license (https:/ / creativecommons.org/licenses/by/ $4.0 /)$.

\begin{abstract}
A rapid and accurate PCR-based method was developed in this study for detecting and identifying a new species of root-lesion nematode (Pratylenchus dakotaensis) recently discovered in a soybean field in North Dakota, USA. Species-specific primers, targeting the internal transcribed spacer region of ribosomal DNA, were designed to be used in both conventional and quantitative real-time PCR assays for identification of P. dakotaensis. The specificity of the primers was evaluated in silico analysis and laboratory PCR experiments. Results showed that only P. dakotaensis DNA was exclusively amplified in conventional and real-time PCR assays but none of the DNA from other control species were amplified. Detection sensitivity analysis revealed that the conventional PCR was able to detect an equivalent to $1 / 8$ of the DNA of a single nematode whereas real-time PCR detected an equivalent to $1 / 32$ of the DNA of a single nematode. According to the generated standard curve the amplification efficiency of the primers in real-time PCR was $94 \%$ with a $\mathrm{R}^{2}$ value of 0.95 between quantification cycle number and $\log$ number of $P$. dakotaensis. To validate the assays to distinguish P. dakotaensis from other Pratylenchus spp. commonly detected in North Dakota soybean fields, 20 soil samples collected from seven counties were tested. The PCR assays amplified the DNA of $P$. dakotaensis and discriminated it from other Pratylenchus spp. present in North Dakota soybean fields. This is the first report of a species-specific and rapid PCR detection method suitable for use in diagnostic and research laboratories for the detection of $P$. dakotaensis.
\end{abstract}

Keywords: detection; DNA; endomigratory; identification; in silico analysis; ITS rDNA; conventional PCR; Pratylenchus dakotaensis; real-time PCR; root-lesion nematode

\section{Introduction}

Root-lesion nematodes, Pratylenchus spp., are one of the most economically important nematode pests of crops worldwide [1]. These plant-parasitic nematodes have a migratory endoparasitic nature, ability to reproduce sexually and/or asexually, excellent adaptability to diverse environmental conditions, and broad host range [2]. Thus, they are ranked as the third most important group of plant-parasitic nematodes after root-knot nematodes and cyst nematodes [3]. Furthermore, there are over 70 described species of Pratylenchus affecting crops of major economic importance [4], including cereals, coffee, fruits, ornamental crops, peanuts, soybeans, and vegetables, resulting in serious economic losses for growers throughout the world [2,4].

Numerous studies have reported high yield losses caused by root-lesion nematodes in infested crop fields. In Australia, P. thornei was reported to cause yield losses in wheat as high as $85 \%$ [5]. In Oregon USA, P. neglectus reduced the yield of intolerant wheat cultivars by $36 \%$ [6]. In Norway, P. penetrans caused tuber lesions and reduced potato yield by $50 \%$ in affected fields [7]. In Brazil, P. brachyurus was reported to cause $21 \%$ yield reduction in soybean fields [8]. Hence, appropriate and effective management of these nematode diseases is critical for improving crop production worldwide. The most 
commonly used management strategies against Pratylenchus spp. include crop rotation and host resistance [9]. Choice of crops available for rotation depends on the identity of the species of root-lesion nematode present in the field because the host range of each Pratylenchus sp. can vary and only a few plant species and cultivars are known to be immune or possess some level of resistance against these plant-parasitic nematodes [2].

The species identity of root-lesion nematodes is often determined using traditional microscopic methods, which utilizes subtle morphological differences such as vulval position, stylet length, body length, postuterine sac length, and lip annule number [2,10]. However, such methods are highly time-consuming because it requires experienced nematologists to collect detailed microscopic measurements from multiple nematode specimens from each field to generate morphometric values [2,10]. Furthermore, multiple species of Pratylenchus can coexist in a single field, making it more challenging to identify Pratylenchus spp. [11-13]. On the other hand, molecular technologies provide several rapid, reliable, and efficient DNA-based diagnostic methods for the species identification of root-lesion nematodes.

One of the first such molecular diagnostic studies on root-lesion nematodes was described by Pinochet et al. [14] that identified and differentiated isolates of P. vulnus using random amplified polymorphic DNA (RAPD) polymerase chain reaction (PCR). Since then, numerous studies have identified and differentiated Pratylenchus spp. to the species level using DNA-based molecular diagnostic methods such as PCR restriction fragment length polymorphism (RFLP), species-specific PCR, and DNA sequencing [15-22]. The RFLP potion of the RFLP-PCR is an additional time-consuming step that is not amenable to commercial high-throughput applications [22]. Although recent advances in sequencing technology simplified the sequencing process, it can still be relatively expensive when a large number of samples need to be diagnosed. Species-specific PCR being a simple, rapid, and relatively inexpensive method, is commonly used in nematology research for diagnostic purposes [3,17].

Conventional species-specific PCR method uses PCR amplification with speciesspecific primers followed by gel electrophoresis to identify the species of the target organism based on bands visible in agarose gel. These species-specific primers are often designed based on sequence information of ribosomal DNA (rDNA) such as the D2-D3 expansion region of $28 \mathrm{~S}$ rDNA and internal transcribed spacer (ITS) of rDNA $[2,17]$. Additionally, specific genes such as cytochrome c oxidase gene, $\beta-1,4$-endoglucanase gene, and major sperm protein gene are commonly used to design species-specific primers in plant-nematology [2].

Al-Banna et al. [15] developed conventional PCR assays with five forward speciesspecific primers, PNEG, PSCR, PPEN, PTHO, and PVUL, to identify and differentiate P. neglectus, P. scribneri, P. penetrans, P. thornei, and P. vulnus, respectively. Each of the five forward primers and a single common reverse primer were designed from the D3 expansion region of $28 \mathrm{~S} \mathrm{rDNA}$. However, the difference in amplicon size between some of the target species was as little as two base-pairs. Thus, Yan et al. [22] modified and designed the PNEG-F1/D3B5 primer set, which could specifically identify P. neglectus by conventional PCR. Additionally, Yan et al. [22] optimized the amplification conditions for the PTHO/D3B primer set to successfully identify P. thornei. Mekete et al. [23] designed the PP5 primer set from ITS rDNA region to identify P. penetrans using conventional PCR and multiplex PCR assays. Huang and Yan [17] designed the PSF7/PSR7 primer set from the ITS-rDNA region to identify P. scribneri. Moreover, Huang and Yan [17] reported that the PSF7/PSR7 primer set was equally effective in identifying P. scribneri using conventional and real-time PCR. Compared to conventional PCR, real-time PCR is a molecular diagnostic technique that has higher detection sensitivity, provides quantitative data, and allows realtime data monitoring [24]. Many other studies have also developed species-specific primers for detection of root-lesion nematode species such as P. brachyurus, P. coffeae, P. crenatus, P. loosi, P. neglectus, P. penetrans, P. scribneri, P. thornei, and P. zeae using species-specific PCR or real-time PCR [16,19-21,25-27]. 
In North Dakota, during 2015 and 2016, soil surveys of soybean fields were conducted to determine the prevalence and distribution of plant-parasitic nematodes in these fields [28]. During the surveys, six soil samples were collected from a soybean field in Walcott, Richland County, ND. After extracting nematodes from these samples, it was evident that root-lesion nematodes were present in all of these samples with population densities ranging from 125 to 2000 nematodes per kg of soil. Morphological measurement of adult males and females and DNA sequencing of 28S D2-D3 (GenBank accession: KX889989) and ITS rDNA (KX889990) revealed that this nematode differs from other known species of rootlesion nematodes in both morphology and DNA sequences [28]. Greenhouse experiments proved that this Pratylenchus species reproduced well on soybeans with a reproductive factor (final population/initial population) as high as 5.02, thus, allowing us to conclude that this is a new species of Pratylenchus that had never been reported in the literature prior to 2017. Recently, Handoo et al. [29] named this new species of root-lesion nematodes as Pratylenchus dakotaensis, paying homage to the state in which it was discovered. However, no species-specific PCR diagnostic method exists to identify this nematode species prior to this study. In order to detect and distinguish P. dakotaensis from other Pratylenchus spp., new species-specific primers need to be exploited for the development of an efficient and sensitive detection system.

The objectives of this research were to develop conventional and real-time PCR assays with species-specific primers for rapid, reliable, and sensitive detection of $P$. dakotaensis, and to evaluate the capability of the assays to discriminate between P. dakotaensis and other commonly found Pratylenchus spp. in North Dakota soybean fields.

\section{Results}

\subsection{Species-Specific PCR Primer Design}

The multiple sequence alignment of the ITS rDNA from Pratylenchus spp. revealed a unique region in the genome of $P$. dakotaensis that is polymorphic between different species. The species-specific primer set, IC-ITS1F/IC-ITS1R designed based on the region was expected to amplify a specific 194-bp fragment of the ITS rDNA of $P$. dakotaensis. The percent GC content for the 18-bp forward primer (IC-ITS1F) was $50 \%$, whereas the percent GC content for the 22-bp reverse primer (IC-ITS1R) was $41 \%$. The predicted annealing temperatures for IC-ITS1F and IC-ITS1R were estimated as 57.6 and $58.9^{\circ} \mathrm{C}$, respectively. Additionally, the primers had a low potential for duplex formation through hairpin formation, self-dimerization, and heterodimer formation. Using the BLAST search function of the $\mathrm{nr} / \mathrm{nt}$ database of NCBI for the initial specificity screening revealed that the primer sequences have no perfect match with non-target plant-parasitic or non-plantparasitic nematodes and no strong similarity to other soil microorganisms.

The IC-ITS1F and IC-ITS1R primers were predicted to have strong and specific annealing with the ITS rDNA sequence of $P$. dakotaensis based on primer-template duplex stability $(\Delta \mathrm{G})$ values of the in silico analysis (Table 1 ). Since $\Delta \mathrm{G}$ values less than $-31 \mathrm{kcal} / \mathrm{mol}$ predict stable primer-template hybrid formation, the IC-ITS1F and IC-ITS1R primers, having a $\Delta \mathrm{G}$ value of -33.5 and -38.4 , respectively, were predicted to hybridize with the ITS rDNA sequence of $P$. dakotaensis [20,30]. Values of $\Delta \mathrm{G}$ higher than $31 \mathrm{kcal} / \mathrm{mol}$ are indicative of unstable primer-template binding resulting in unidirectional or non-logarithmic amplification, which are not competitive with specific amplification. Thus, IC-ITS1F forward primer was predicted to hybridize poorly with ITS rDNA sequences of the three P. neglectus populations used in silico analysis, having a $\Delta \mathrm{G}$ value of -14.4 . On the other hand, the IC-ITS1R reverse primer was predicted to form insignificant $(\Delta G=$ ins) hybrid with ITS rDNA sequences of $P$. neglectus $[20,30]$. In addition to that, both the primers were not predicted to result in primer-template duplexes with the ITS rDNA sequences of any other Pratylenchus spp. used in silico analysis (Table 1). Hence, the primer set IC-ITS1F/IC-ITS1R was predicted to specifically amplify the DNA of P. dakotaensis. Therefore, this primer set was selected for further laboratory experiments. 
Table 1. Populations of Pratylenchus spp. and their corresponding GenBank accession numbers of internal transcribed spacer (ITS) sequences used for analysis of primer-template duplex stability $(\Delta \mathrm{G})$ for predicting the specificity of primers, IC-ITS1F and IC-ITS1R.

\begin{tabular}{|c|c|c|c|c|c|c|}
\hline \multirow{2}{*}{ Species } & \multirow{2}{*}{$\begin{array}{l}\text { GenBank } \\
\text { Accession }\end{array}$} & \multirow{2}{*}{$\begin{array}{l}\text { Sample ID or Clone } \\
\text { ID }^{\text {a }}\end{array}$} & \multirow{2}{*}{ Origin } & \multirow{2}{*}{$\begin{array}{l}\text { Sequence } \\
\text { Length (bp) }\end{array}$} & \multicolumn{2}{|c|}{$\Delta \mathrm{G}(\mathrm{kcal} / \mathrm{mole})^{\mathrm{b}}$} \\
\hline & & & & & IC-ITS1F & IC-ITS1R \\
\hline P. dakotaensis ${ }^{\mathrm{c}}$ & KX889990.1 & $\operatorname{Hg} 50$ & ND, USA & 1126 & -33.5 & -38.4 \\
\hline Pratylenchus sp. ${ }^{\mathrm{d}}$ & KY200666.1 & Hg51 & ND, USA & 981 & ins & ins \\
\hline P. agilis & KC952982.1 & SX/Clone7 & P.R. China & 882 & ins & ins \\
\hline P. agilis & FJ712891.1 & PagKL5/Clone5 & Belgium & 880 & ins & ins \\
\hline P. alleni & JX081545.2 & $\mathrm{N} / \mathrm{A}$ & Canada & 1080 & ins & ins \\
\hline P. bolivianus & HM469446.1 & TW2 & P.R. China & 1163 & ins & ins \\
\hline P. brachyurus & MH020807.1 & AD70 & Spain & 627 & ins & ins \\
\hline P. coffeae & JX046940.1 & YT/Clone4 & P.R. China & 1102 & ins & ins \\
\hline P. convallariae & HM469448.1 & $\mathrm{N} / \mathrm{A}$ & P.R. China & 722 & ins & ins \\
\hline P. crenatus & LC030310.1 & He1/Clone1 & Japan & 928 & ins & ins \\
\hline P. crenatus & LC030308.1 & Pcr-H01/Clone1 & Japan & 958 & ins & ins \\
\hline P. fallax & KY828273.1 & V4C/Clone180 & Belgium & 755 & ins & ins \\
\hline P. goodeyi & KF700243.1 & CICR-Cot.Warud & India & 782 & ins & ins \\
\hline P. gutierrezi & KT971367.1 & O22_1 & Spain & 906 & ins & ins \\
\hline P. hippeastri & KR029085.1 & QIXIA & China & 1185 & ins & ins \\
\hline P. jaehni & FJ712937.1 & PjaKL1/Clone & Belgium & 997 & ins & ins \\
\hline P. lentis & AM933154.1 & $\begin{array}{l}\text { Individual Nematode } \\
10\end{array}$ & Italy & 703 & ins & ins \\
\hline P. loosi & KY424222.1 & EX11 & P.R. China & 1212 & ins & ins \\
\hline P. mediterraneus & FR692306.1 & $\mathrm{N} / \mathrm{A}$ & Italy & 946 & ins & ins \\
\hline P. neglectus & LC030328.1 & NM1/Clone8 & Japan & 852 & -14.4 & ins \\
\hline P. neglectus & LC030323.1 & HT2KU1/Clone1 & Japan & 871 & -14.4 & ins \\
\hline P. neglectus & LC030325.1 & HKf1/Clone6 & Japan & 855 & -14.4 & ins \\
\hline P. penetrans & LC030336.1 & HM1/Clone3 & Japan & 874 & ins & ins \\
\hline P. pinguicaudatus & KY828261.1 & T572/Clone168 & Belgium & 762 & ins & ins \\
\hline P. pratensis & KY828311.1 & T616/Clone 232 & Belgium & 807 & ins & ins \\
\hline P. pseudocoffeae & LC030337.1 & Pps-KM1/Clone1 & Japan & 1090 & ins & ins \\
\hline P. pseudocoffeae & LC030339.1 & Pps-KM1/Clone7 & Japan & 1090 & ins & ins \\
\hline P. scribneri & KT873860.1 & ND & ND, USA & 1103 & ins & ins \\
\hline P. scribneri & KX842626.1 & F21 & ND, USA & 1103 & ins & ins \\
\hline P. scribneri & JX046934.1 & XC/Clone2 & P.R. China & 957 & ins & ins \\
\hline P. thornei & FR692305.1 & Pt_Je_SP_cl13 & Italy & 1001 & ins & ins \\
\hline P. thornei & FR692304.1 & PT_SI_IT_cl19 & Italy & 974 & ins & ins \\
\hline P. vulnus & KY424232.1 & JSR & China & 925 & ins & ins \\
\hline P. zeae & FJ643590.1 & $\mathrm{N} / \mathrm{A}$ & Republic of China & 967 & ins & ins \\
\hline
\end{tabular}

${ }^{a}$ Names of samples or clones were obtained from GenBank. N/A indicates that the information is not available in GenBank. ${ }^{b}$ Values of $\Delta \mathrm{G}<-31 \mathrm{kcal} / \mathrm{mol}$ indicate stable primer-template duplex formation for PCR amplification, conversely, values $>-31 \mathrm{kcal} / \mathrm{mol}$ indicate poor primer-template duplex stability for PCR amplification; 'ins' indicate very poor or insignificant primer-template duplex stability values. ${ }^{c}$ The Hg50 nematode sample is the target species of Pratylenchus (P. dakotaensis) investigated in this study. ${ }^{\mathrm{d}}$ The Hg51 nematode sample is another species of Pratylenchus newly identified in North Dakota (ND), USA, which is different from P. dakotaensis.

\subsection{Primer Specificity}

Laboratory conventional and real-time PCR assays confirmed the prediction of in silico analysis about the specificity of the newly designed primers. As expected, the ICITS1F/IC-ITS1R primer set amplified a specific 194-bp DNA fragment of the target species of Pratylenchus (P. dakotaensis). A single specific amplicon was observed in the conventional PCR assay with all four populations $P$. dakotaensis used in the specificity tests (Table 2, sample ID: Hg50-1, Hg50-2, Hg50-3, and Hg50-4). Additionally, all DNA extracted from different numbers of the target individuals $(4,2,1$, and 0.5$)$ from the same population produced the specific amplicon in conventional PCR (Table 2, Hg50-4). No amplification was observed in the conventional PCR assay with non-target control species consisting of multiple populations of five other confirmed Pratylenchus spp., eight other genera of plant-parasitic nematodes, and two genera of non-plant-parasitic nematodes. Conventional 
PCR also amplified DNA from each of the target and non-target species using the universal primers rDNA2/rDNA1.58s, confirming the presence of template DNA in each of the samples tested. As expected, real-time PCR amplifications with the non-target control species yielded no fluorescence signal, thus $\mathrm{Cq}$ values were not detectable. However, $\mathrm{Cq}$ values ranging from $26.43 \pm 0.05$ to $30.64 \pm 0.50$ were recorded from real-time PCR with the various populations of $P$. dakotaensis at varying numbers of $P$. dakotaensis individuals in DNA extracts (Table 2). Melting curve analysis revealed a single melting peak at $81.5^{\circ} \mathrm{C}$ and no secondary curves confirming a single amplicon specific for each of the four populations of $P$. dakotaensis (Figure 1). For both conventional and real-time PCR assays, no amplicons were generated in non-template controls containing water instead of DNA.

Table 2. Taxon, geographic origin, current crop, and polymerase chain reaction (PCR) assays of the control nematode species used to test the specificity of IC-ITSF/ITS1R primer set designed to identify and detect P. dakotaensis.

\begin{tabular}{|c|c|c|c|c|c|c|}
\hline \multirow{2}{*}{ Sample ID ${ }^{a}$} & \multirow{2}{*}{ Species } & \multirow{2}{*}{ Origin } & \multirow{2}{*}{ Crop $^{b}$} & \multirow{2}{*}{$\#$ of Nema ${ }^{c}$} & \multicolumn{2}{|c|}{ PCR Assay } \\
\hline & & & & & Conventional $^{\mathrm{d}}$ & $\operatorname{RT}(\mathrm{Cq})^{\mathrm{e}}$ \\
\hline Ps1 & $\begin{array}{l}\text { Pratylenchus } \\
\text { scribneri }\end{array}$ & Sargent, ND, USA & Corn & 2 & - & $\mathrm{N} / \mathrm{A}$ \\
\hline Ps2 & P. scribneri & Sargent, ND, USA & Potato & 2 & - & $\mathrm{N} / \mathrm{A}$ \\
\hline Pn1 & P. neglectus & Richland, ND, USA & Corn & 2 & - & $\mathrm{N} / \mathrm{A}$ \\
\hline Pn2 & P. neglectus & Bottineau, ND, USA & Field Pea & 2 & - & $\mathrm{N} / \mathrm{A}$ \\
\hline $\mathrm{Pt}$ & P. thornei & OR, USA & Wheat & 2 & - & $\mathrm{N} / \mathrm{A}$ \\
\hline $\mathrm{Pp}$ & P. penetrans & Sherburne, MN, USA & Potato & 2 & - & $\mathrm{N} / \mathrm{A}$ \\
\hline Tyl & Tylenchorhychus sp. & Richland, ND, USA & Corn & 2 & - & $\mathrm{N} / \mathrm{A}$ \\
\hline Spi & Helicotylenchus sp. & Richland, ND, USA & Soybean & 2 & - & $\mathrm{N} / \mathrm{A}$ \\
\hline Xph & Xiphinema sp. & Sargent, ND, USA & Potato & 2 & - & $\mathrm{N} / \mathrm{A}$ \\
\hline Prt & Paratylenchus sp. & McIntosh, ND, USA & Corn & 2 & - & $\mathrm{N} / \mathrm{A}$ \\
\hline Ptr & Paratrichodorus sp. & Sargent, ND, USA & Potato & 2 & - & $\mathrm{N} / \mathrm{A}$ \\
\hline Hop & Hoplolaimus sp. & Sargent, ND, USA & Soybean & 2 & - & $\mathrm{N} / \mathrm{A}$ \\
\hline $\mathrm{SCN}$ & Heterodera glycines & Richland, ND, USA & Soybean & 2 & - & $\mathrm{N} / \mathrm{A}$ \\
\hline SBCN & H. schachtii & Richland, MT, USA & Sugarbeet & 2 & - & $\mathrm{N} / \mathrm{A}$ \\
\hline NPN1 & $\begin{array}{c}\text { Non-plant parasitic } \\
\text { nematode } 1\end{array}$ & Richland, ND, USA & Corn & 2 & - & $\mathrm{N} / \mathrm{A}$ \\
\hline NPN2 & $\begin{array}{l}\text { Non-plant parasitic } \\
\text { nematode } 2\end{array}$ & Richland, ND, USA & Soybean & 2 & - & $\mathrm{N} / \mathrm{A}$ \\
\hline Hg51 & Pratylenchus sp. & Richland, ND, USA & Soybean & 2 & - & $\mathrm{N} / \mathrm{A}$ \\
\hline Hg50-1 & P. dakotaensis & Richland, ND, USA & Soybean & 2 & + & $28.91 \pm 0.40$ \\
\hline Hg50-2 & P. dakotaensis & Richland, ND, USA & Soybean & 2 & + & $27.70 \pm 0.10$ \\
\hline Hg50-3 & P. dakotaensis & Richland, ND, USA & Corn & 2 & + & $28.02 \pm 0.59$ \\
\hline Hg50-4 & P. dakotaensis & Richland, ND, USA & Soybean & 4 & + & $26.43 \pm 0.05$ \\
\hline Hg50-4 & P. dakotaensis & Richland, ND, USA & Soybean & 2 & + & $27.60 \pm 0.20$ \\
\hline Hg50-4 & P. dakotaensis & Richland, ND, USA & Soybean & 1 & + & $29.87 \pm 0.50$ \\
\hline Hg50-4 & P. dakotaensis & Richland, ND, USA & Soybean & 0.5 & + & $30.64 \pm 0.50$ \\
\hline
\end{tabular}

${ }^{a}$ Each of the nematode samples used in the primer specificity tests were collected by the North Dakota State University Nematology Laboratory from different field locations in North Dakota, Minnesota, and Montana except for the P. thornei sample (sample ID: Pt), which was acquired from Oregon State University. Samples with the sample ID Hg50-1-4 are target species (P. dakotaensis) and the remaining samples in the table are non-target control species. The Hg51 nematode sample is another species of Pratylenchus newly identified in North Dakota (ND), USA, which is different from P. dakotaensis. ${ }^{b}$ The crop that was planted during the growing season, in which the samples were collected. ${ }^{c}$ For each of the control species used in the specificity tests, DNA was extracted from 2 individuals. For the target nematode species used in the specificity tests, DNA was extracted from $0.5,1,2$, and 4 individuals. ${ }^{d}$ The positive (+) and negative $(-)$ symbols indicate that the target amplicon was detected or not detected, respectively, in conventional PCR assays with the designed primer set specific to $P$. dakotaensis. ${ }^{e}$ The quantification cycle $(\mathrm{Cq})$ value has been presented as the mean \pm standard deviation of three technical replicates. 


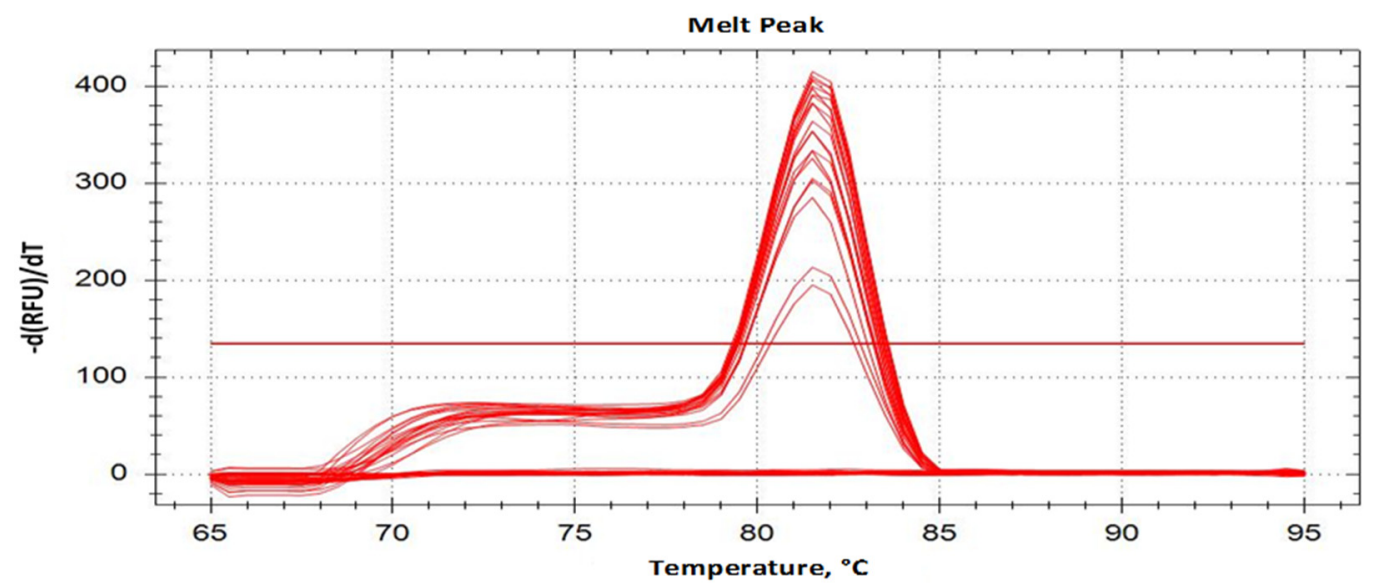

Figure 1. Melting curve profiles of $P$. dakotaensis. Amplicons with a single peak at a melting temperature of $81.5^{\circ} \mathrm{C}$ were observed for populations of P. dakotaensis.

\subsection{Detection Sensitivity of the PCR Assays}

The sensitivity was determined using DNA from each dilution level of a sequential two-fold serial dilution of DNA extracted from four $P$. dakotaensis individuals in both conventional and real-time PCR assays. As expected, with each dilution of template DNA the intensity of PCR bands gradually decreased in the conventional PCR assay, and the Cq values were continuously increased in the real-time PCR assay (Figure 2). According to gel electrophoresis of conventional PCR products on $2 \%$ agarose gel, the assay was able to amplify the DNA of four $P$. dakotaensis individuals diluted down five times $(4,2,1,1 / 2,1 / 4$, and $1 / 8)$ to an equivalent of $1 / 8$ of a single nematode. However, DNA from 6 th $(1 / 16)$, 7th (1/32), and 8th (1/64) dilutions were not amplified by the conventional PCR indicated by the absence of bands on $2 \%$ agarose gel, suggesting that the IC-ITS1F/IC-ITS1R primer set could detect an equivalent to $1 / 8$ of the DNA of a single P. dakotaensis individual. In the real-time PCR assay, DNA from each dilution level was used to generate a standard curve. The equation for the standard curve was determined as $y=-3.474 x+29.002$, with an $\mathrm{R}^{2}$ value of 0.9467 and an efficiency (E) of $94.02 \%$. Thus, the standard curve generated showed a strong negative correlation between the Cq values from real-time PCR and the $\log$ values of numbers of $P$. dakotaensis (Figure 3). Since the amplification efficiency and the $\mathrm{R}^{2}$ value were high and within the acceptable range, the IC-ITS1F/IC-ITS1R primer set was considered suitable for real-time PCR assay. The sensitivity of the real-time PCR assay was also determined. The assay was able to amplify the DNA of four individuals diluted seven times $(4,2,1,1 / 2,1 / 4,1 / 8,1 / 16$, and $1 / 32)$, with the Cq values ranging from $26.57 \pm 0.30$ to $33.74 \pm 0.32$ (Figure 2) and the DNA from the 8th dilution $(1 / 64)$ was not amplified, suggesting this primer set could detect an equivalent to $1 / 32$ of the DNA of a single nematode in the real-time PCR assay.

\subsection{Identification of Pratylenchus spp. Collected from Soybean Fields}

The 20 soil samples collected from soybean fields or fields with a history of soybean production across seven soybean producing counties of North Dakota (Cass, Dickey, Grand Forks, Nelson, Richland, Sargent, and Wells) were all positive with Pratylenchus spp. The population densities of Pratylenchus spp. in these field soil samples ranged from 15 to 360 nematodes per $100 \mathrm{~cm}^{3}$ of soil (Table 3). Out of the 20 samples, 12 were determined to be $P$. neglectus whereas seven were determined to be P. scribneri through published species-specific PCR assays. The IC-ITS1F/IC-ITS1R primer set designed in this study did not amplify any of those 19 samples, however it was able to amplify the DNA of root-lesion nematodes obtained from a soil sample (Table 3, sample ID: 50 RL 3) that was collected from a field that is neighboring the field where P. dakotaensis was first detected and from a soil sample collected from the original field (HG50-0). Subsequent direct sequencing of 
D2-D3 expansion region of 28S rDNA and ITS rDNA region validated that 50 RL 3 was infested with $P$. dakotaensis.

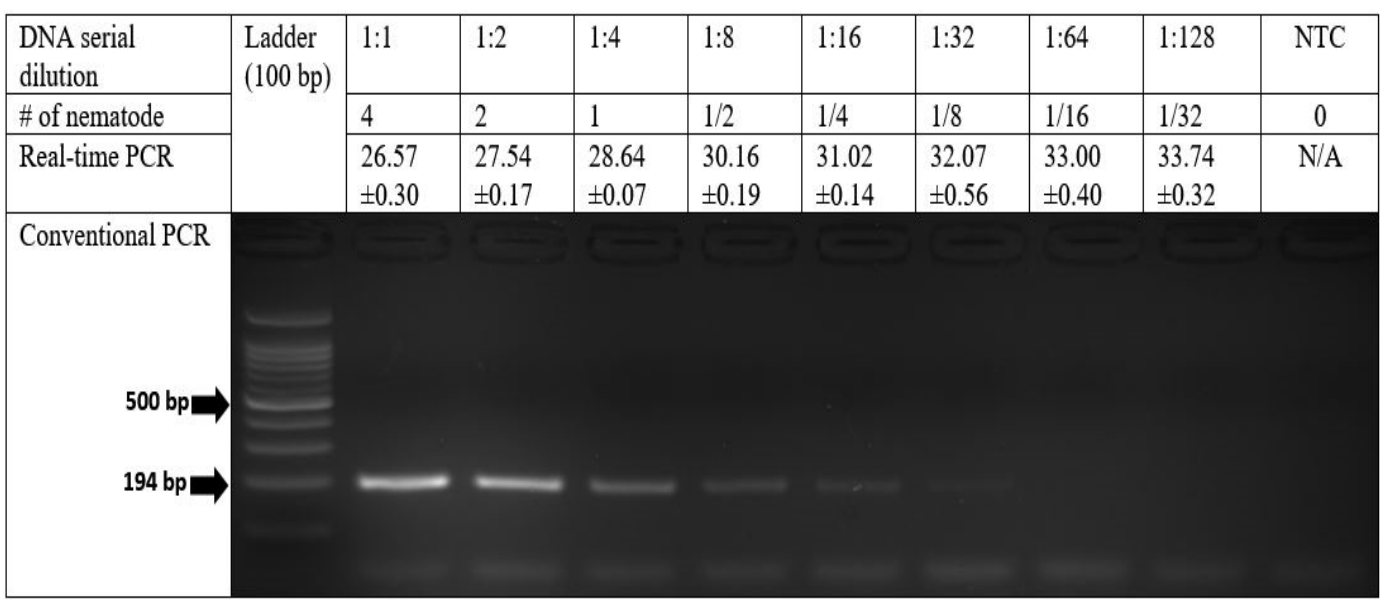

Figure 2. Amplification sensitivity of the IC-ITS1F/IC-ITS1R primer set in conventional polymerase chain reaction (PCR) compared to real-time PCR. The quantification cycle $(\mathrm{Cq})$ value is presented as the mean \pm standard deviation of three technical replicates of one of the biological replicates used for standard curve development. DNA was extracted from 4 P. dakotaensis individuals and sequential two-fold serial dilutions $(2,1,1 / 2,1 / 4,1 / 8,1 / 16,1 / 32$, and 1/64) were conducted, but the last dilution level 1:256 (1/64) was not included in this figure.

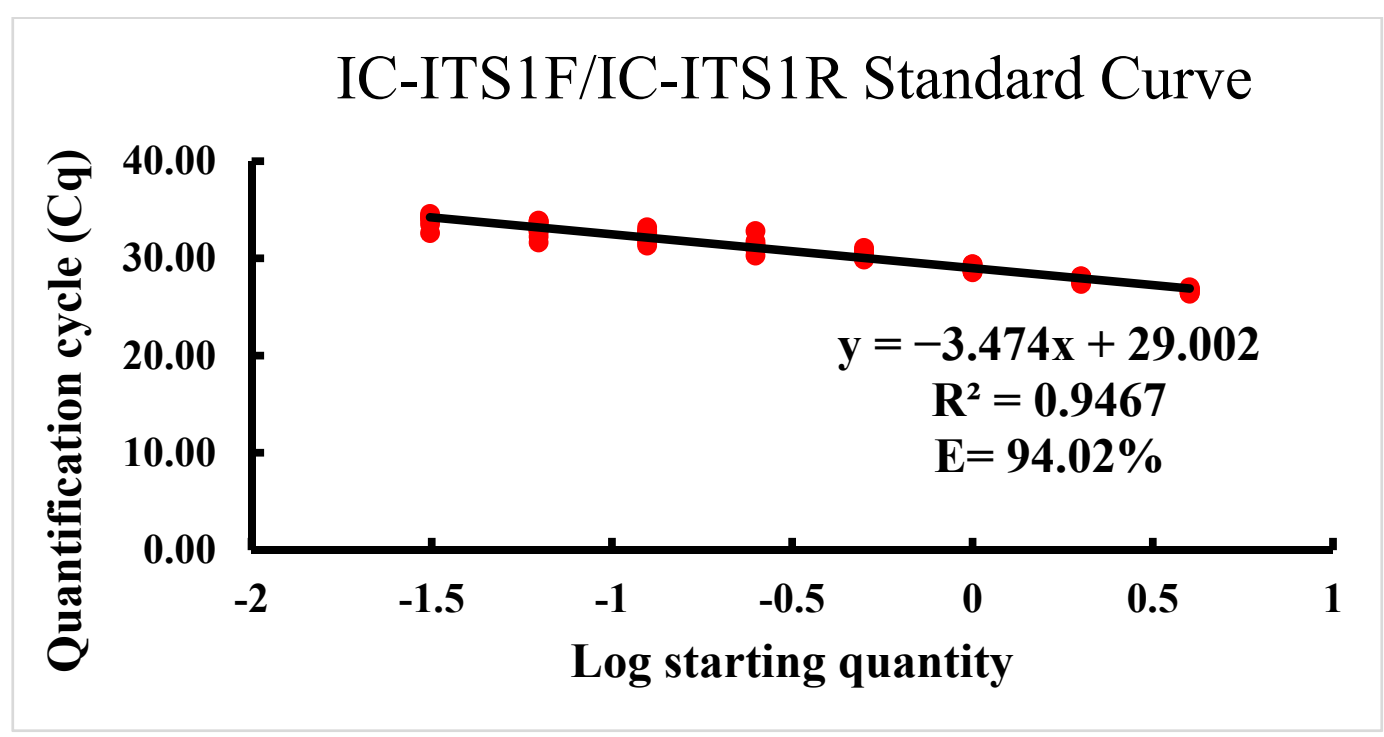

Figure 3. Standard curve of the real-time PCR assay for the new species of Pratylenchus detected in a soybean field of North Dakota: quantification cycle number $(\mathrm{Cq})$ plotted against the log number of individuals of $P$. dakotaensis by sequential two-fold dilutions $(4,2,1,1 / 2,1 / 4,1 / 8,1 / 16,1 / 32$, and 1/64). Each red dot represents an independent reaction run in triplicate for three biological replicates at each dilution level. The efficiency $(\mathrm{E})$ of amplification was calculated as $\mathrm{E}=1^{1 /-m}$ -1 , where $m$ indicates the slope. 
Table 3. Identification of Pratylenchus spp. collected from 20 soybean fields in North Dakota by species-specific polymerase chain reaction (PCR) assays a

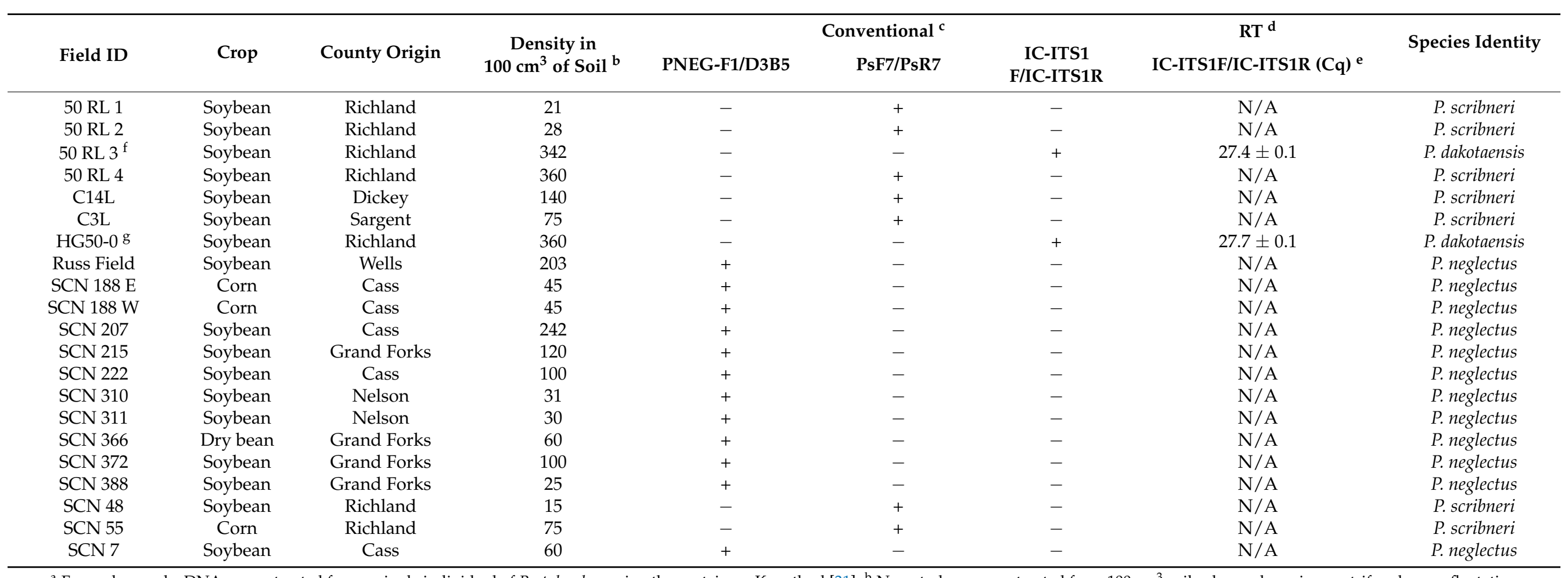

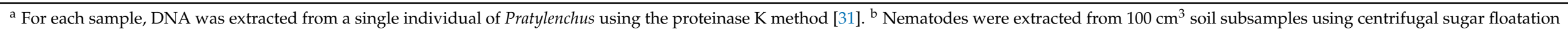

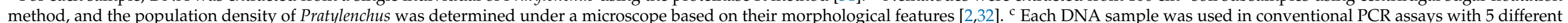

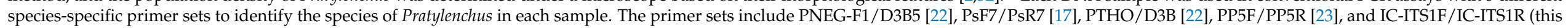

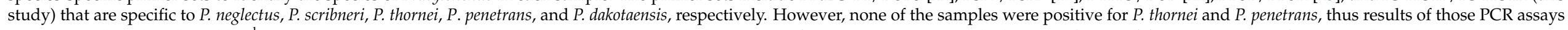

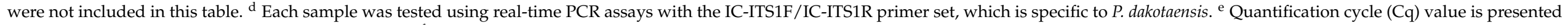

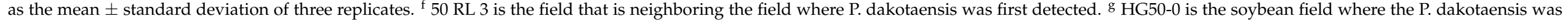
originally detected. 


\section{Discussion}

Pratylenchus spp. are one of the most economically important pests of field crops $[3,33]$. However, the potential of root-lesion nematodes to cause economic loss can vary according to the species present and their population density [34]. Therefore, diagnostic assays that can effectively identify the species of Pratylenchus are of the utmost importance to facilitate their management. Conventional and real-time PCR continues to be amongst the most important diagnostic tools in plant nematology research [3], since they are relatively inexpensive, less time consuming, accurate, and easy to use.

Both conventional and real-time PCR have advantages of their own, compared to each other. While conventional PCR is more inexpensive, easy to use, and less affected by PCR inhibitors [35], real-time PCR is less time consuming, more sensitive, allows continuous monitoring of data, and provides quantitative data [20]. Thus, we designed and developed a conventional PCR assay, and a SYBR Green-I based real-time PCR assay, for identification and quantitative detection of P. dakotaensis, which is a new species of Pratylenchus recently discovered in a soybean field in North Dakota [28,29]. The IC-ITS1F/IC-ITS1R primer set designed was able to specifically and sensitively amplify the DNA of P. dakotaensis in both conventional and real-time PCR assays. Moreover, the designed primer set was able to successfully detect and differentiate the P. dakotaensis from other confirmed Pratylenchus spp. collected from 20 other fields of North Dakota. Hence, we report for the first time, two efficient molecular methods for detection and identification of a new species of Pratylenchus (P. dakotaensis) detected in North Dakota [28].

The IC-ITS1F/IC-ITS1R species-specific primer set was designed from the ITS rDNA region of P. dakotaensis' genome. Numerous ITS-region based PCR assays have been developed to identify and differentiate plant-parasitic nematodes to their species level [17,25,30,36-41]. Compared to $28 \mathrm{~S}$ rDNA and $18 \mathrm{~S}$ rDNA that are conserved through evolution, the ITS rDNA region is considered to be more variable among genera and species of plant-parasitic nematodes and other soil-borne organisms $[17,42,43]$. Although, several studies have developed species-specific primers that were designed from the $18 \mathrm{~S}$ rDNA and 28S rDNA [15,16,22], the ITS rDNA sequences are known to have greater variability between different Pratylenchus spp. [17,19,42]. Several other nematode genes such as mitochondrial cytochrome oxidase 1, mitochondrial cytochrome oxidase 2,16D10 effector gene, and chorismate mutase effector gene have been used, in recent studies, to design species-specific primers for identification of nematode species [44-48]. However, in our literature review we found that more ITS rDNA sequences of plant-parasitic nematodes and Pratylenchus spp. were available in GenBank and previous literature compared to these genes, which facilitated our sequence analysis and comparison when designing the primers.

The performance of species-specific primers in PCR is substantially influenced by primer length, melting temperature $\left(T_{m}\right)$, GC content, and potential for self-dimer or primer dimer formation [49]. The specificity of a primer pair is generally controlled by their sequence length and the annealing temperature used in PCR reaction. Primers that are 18-24 bp in length are considered to be the best in being sequence specific if the annealing temperature of the PCR reaction is set within $5{ }^{\circ} \mathrm{C}$ of the primer $T_{m}[49,50]$. On the other hand, primers with $50-60 \%$ GC content ensure optimal binding strength of primertemplate duplex because the $\mathrm{G}$ and $\mathrm{C}$ bases have stronger hydrogen bonding, and the binding strength of the primer-template duplex determines the efficiency of annealing [51]. Moreover, the presence of G or C bases at the $5^{\prime}$ and $3^{\prime}$ end ensures a GC clamp and promotes specific binding. Another important factor to consider when designing a primer is the potential of the primers to form secondary structures. Presence of complementary sequence within the primer length can result in hairpin or self-dimer formation, whereas homology between the forward and reverse primer can lead to primer dimer formation [52]. These secondary structures can directly compete with the template in PCR, negatively affecting species-specific amplification [50]. Thus, the IC-ITS1F and IC-ITS1R primers were designed to have optimal primer length, melting temperature $\left(T_{m}\right)$, GC content, and low potential for secondary structure formation. 
Numerous previous molecular diagnostic studies have used in silico analysis to predict the performance of primers regarding specificity against multiple populations of their respective target species and non-target species [20-22,25,30,53-55]. The in silico analysis provided us an opportunity to predict the specificity of the primers against the DNA sequences of multiple populations of 26 other important species of Pratylenchus originating from different regions of the world. Results of in silico analysis predicted that the primers were highly specific to $P$. dakotaensis. The specificity of the primers was further confirmed through laboratory PCR assays with multiple populations of $P$. dakotaensis and multiple populations of five other Pratylenchus spp. along with non-target control species in eight other genera. Since DNA from each of the target nematode population were amplified by the designed primers and none of the non-target species' DNA were amplified, the results of the PCR specificity tests were consistent with the predictions obtained from the in silico analysis. This indicates that the IC-ITSF/IC-ITS1R primer set can be successfully used in both conventional and real-time PCR assays to distinguish and identify P. dakotaensis from other plant-parasitic nematode species evaluated. Nevertheless, Pratylenchus is a diverse genus containing more than 70 species (4). Further testing of these primers with other Pratylenchus spp. and local species in soil may be necessary if these primers were used for diagnosis in other geographic regions.

Primers that are specific for other Pratylenchus spp. in conventional PCR have been described before $[2,15,22]$. However, not all of those primers could directly be used in real-time PCR due to non-specific amplifications being detected by the greater amplification sensitivity of real-time PCR $[17,21]$. However, the species-specific primers designed in this study can be used in both conventional PCR and real-time PCR for species identification. Applicability of the primers in real-time PCR was demonstrated by the high inverse linear relationship observed between the $\mathrm{Cq}$ values and the log values of nematode numbers $\left(R^{2}=0.95\right)$ revealed by the standard curve generated. Moreover, the standard curve also revealed that the primers had good amplification efficiency $(E=94 \%)$, reflecting on the robustness of real-time PCR assay developed.

Practically, DNA from as little as a single nematode could be used to specifically identify P. dakotaensis using the molecular diagnostic methods developed in this study. As expected, the real-time PCR assay with greater sensitivity could detect an equivalent of $1 / 32$ of a single nematode; whereas, the conventional PCR could detect an equivalent of $1 / 8$ of a single nematode. These results are in agreement with findings from previous studies that developed species-specific primers can be used in both conventional and real-time PCR assays for nematode identification [17,30]. Moreover, the sensitivity of the conventional and real-time PCR assays was comparable to other nematode related PCR assays reported in previous literature, where DNA from less than a single nematode individual could be detected $[17,20,26,30,36,56,57]$. For examples, the real-time PCR assay developed by Berry et al. [26] could detect as little as $2.5 \%(1 / 40)$ of the DNA of a P. zeae individual and the conventional PCR assay developed by Huang and Yan [17] could detect an equivalent of $1 / 4$ of the DNA of a single P. scribneri individual.

The assays developed in this study were able to discriminate between P. dakotaensis and other Pratylenchus spp. commonly present in North Dakota soybean fields. Among the 20 other fields of ND, from which soil samples were collected, a majority were infested with P. scribneri or P. neglectus. Although, several studies reported that multiple species of Pratylenchus could coexist in an individual cropping field [11-13], none of the fields surveyed in this study were found to be infested with more than one species of Pratylenchus by testing three nematode individuals from each field. The IC-ITS1F/IC-ITS1R primer set did not amplify the DNA of $P$. scribneri or P. neglectus obtained from these field samples. However, it was able to amplify the DNA of a Pratylenchus sp. obtained from a soil sample (Table 3, sample ID: 50 RL 3) collected from a neighboring field of the soybean field that was originally infested with P. dakotaensis [28]. Therefore, this study reports for the first time that another soybean field (50 RL 3) of North Dakota is infested with the new species P. dakotaensis. 
In conclusion, the PCR assays developed in this study provides a rapid, specific, and sensitive detection method for P. dakotaensis. Both the specificity and sensitivity of the primers designed were confirmed through extensive testing. Moreover, the standard curve analysis revealed that the primers had a good amplification efficiency. Thus, the ICITS1F/IC-ITS1R primer set is suitable for use in both diagnostic laboratories and research laboratories for the detection of field infestation with this nematode species. The PCR-based methods can be performed on a single nematode, which overcomes the need of morphometric measurements of multiple, decent nematode specimens for species identification, and also can accurately determine species identity without the influence of variations in nematode morphology among different populations of the same species. Therefore, the information presented in this study would be valuable for improving nematode detection to develop nematode management strategies. Moreover, this study will help in the future development of PCR assays that can identify and quantify this nematode species directly from DNA extracts of soil or plant samples. This will simplify the diagnosis process by avoiding the nematodes extraction from soil or plant roots prior to DNA extraction.

\section{Materials and Methods}

\subsection{Soil Sampling and Nematode Extraction from Soil}

Soil samples were collected from a soybean field in Walcott, Richland County, ND, which was previously reported to have been infested with P. dakotaensis [28]. Nematodes were then extracted from the soil samples using the standard hand sieving, decanting, and sugar centrifugal-floatation method [58]. Briefly, this method relies principally on agitating the soil in tap water $(200 \mathrm{~mL})$ through stirring and pouring the mixture through a stack of sieves ( $250 \mu \mathrm{m}$ and $20 \mu \mathrm{m}$ apertures) to separate larger organic and inorganic soil particles from nematodes and smaller soil particles. Then, the smaller soil particles and nematodes that were collected in the $20-\mu \mathrm{m}$-aperture sieve were separated from each other by suspending them in a 1.3 M sucrose solution (American Crystal Sugar Company, Moorhead, MN, USA). Once suspended, the solution was centrifuged at 4000 RPM for $30 \mathrm{~s}$. The supernatant containing the vermiform nematodes was poured through $20-\mu \mathrm{m}$-aperture sieve to remove the sugar solution and the nematodes were then rinsed with tap water and collected in $15 \mathrm{~mL}$ tap water for quantification, and the pellet containing the soil particles was discarded. Subsequently, root-lesion nematodes were identified and enumerated at the genus level based on their key morphological features [32] under a dissecting microscope (Zeiss Stemi 305; Zeiss, Thornwood, NY, USA) at 80× magnification.

\subsection{Root-Lesion Nematode Isolation and DNA Extraction}

Individuals of the Pratylenchus spp. identified to the genus level were isolated from the nematode suspension, and the proteinase K method described by Kumari and Subbotin [31] was then used to extract DNA from the nematodes. According to this method, individual nematodes were hand-picked using a dental pick, placed into a concave slide containing $10 \mu \mathrm{L}$ of sterilized double-distilled water, and cut into two pieces using the dental pick under the dissecting microscope. The $10 \mu \mathrm{L}$ suspension containing the nematode pieces was then pipetted into a $0.5 \mathrm{~mL}$ sterile centrifuge tube containing $10 \mu \mathrm{L}$ of extraction buffer $(2 \mu \mathrm{L}$ of 10X PCR buffer, $2 \mu \mathrm{L}$ of proteinase $\mathrm{K}(\mu \mathrm{g} / \mathrm{mL})$, and $6 \mu \mathrm{L}$ double-distilled water). The tubes containing the extraction buffer and the nematode suspension were then vortexed and frozen at $-20^{\circ} \mathrm{C}$ for at least $30 \mathrm{~min}$. Subsequently, the tubes were incubated at $65^{\circ} \mathrm{C}$ in a water bath for $1 \mathrm{~h}$, followed by incubation at $95^{\circ} \mathrm{C}$ for $10 \mathrm{~min}$ to inactivate the proteinase $\mathrm{K}$ [31].

\subsection{Direct Sequencing for Identity Confirmation}

To confirm the species identity of the root-lesion nematodes extracted from samples that were collected from the field where P. dakotaensis was first discovered [28,29], two genomic regions were sequenced. The universal primers D2A (5'-ACAAGTACCGTGAGGGA AAGTTG-3') and D3B (5'-TCGGAAGGAACCAGCTACTA-3') were used to amplify the 
D2-D3 expansion region of $28 \mathrm{~S}$ rDNA, following the PCR protocol described by Subbotin et al. [59]. Additionally, the universal primers rDNA2-V (5'-TTGATTACGTCCCTGCCCTTT$\left.3^{\prime}\right)$ and PnSeqR (5'-TTTCACTCGCCGTTACTAAGG-3') were used to amplify the ITS rDNA region, as described by Vrain et al. [60]. The PCR products were then purified using the PCR Extract Mini Kit (5 PRIME INC., Gaithersburg, MD, USA) and shipped to Eurofins Genomics (Louisville, KY, USA) for direct sequencing. The sequencing results were evaluated using the BioEdit software version 7.0.9.0 [61] and a Blastn alignment was performed in National Center for Biotechnology Information (NCBI, https: //blast.ncbi.nlm.nih.gov/Blast.cgi, accessed on 4 April 2021) using the nucleotide collection (nr/nt) database to confirm the species identity by comparing to the sequences available in GenBank.

\subsection{Species-Specific PCR Primer Design and Development}

The internal transcribed spacer (ITS) rDNA sequence of $P$. dakotaensis (accession number KX889989) was acquired from GenBank [28]. Additionally, 16 ITS rDNA sequences from 11 other Pratylenchus spp. were collected from GenBank. These ITS sequences with the corresponding accession numbers contained two populations of each of P. agilis (FJ712891.1 and KC952982.1), P. neglectus (LC030328.1 and LC030323.1), P. pseudocoffeae (LC030337.1 and LC030339.1), P. scribneri (KT873860.1 and KX842626.1), and P. thornei (FR692305.1 and FR692304.1) and one population of each of P. alleni (JX081545.2), P. gutierrezi (KT971367.1), P. hippeastri (KR029085.1), P. jaehni (FJ712937.1), P. loosi (KY424222.1), and P. penetrans (LC030336.1). The ITS sequence of $P$. dakotaensis together with the ITS sequences of the 11 other Pratylenchus spp. were aligned using the Clustal W tool of the BioEdit software version 7.0.9.0 [61]. The multiple sequence alignment was used to identify and design a pair of primers, IC-ITS1F (forward, $5^{\prime}$-TGTGTGCGAATGTTCCTG-3') and IC-ITS1R (reverse, $5^{\prime}$-CGTATGTTTTATATGGGGACTC-3'), within the diverse region of ITS rDNA, among the different species of Pratylenchus and the size of the target amplicon was 194 base pairs. The primer set was then assessed on the basis of optimal annealing temperature, GC content, and potential for duplex formation through hairpin formation, self-dimerization, and heterodimer formation using OligoAnalyzer 3.1 (Integrated DNA Technologies, Inc, Croalville, IA, USA).

The primers were initially screened for specificity using the BLAST search function in NCBI to determine if the primers matched with other non-target nucleotide sequences in the nucleotide collection (nr/nt) database. Moreover, the specificity of the primer set was predicted in silico against the 16 ITS rDNA sequences used to design the primers in addition to the ITS sequences of 16 other important Pratylenchus spp. collected from GenBank (Table 1). Primer specificity was determined in silico by evaluating the primer-template duplex stability values $(\Delta \mathrm{G})$ calculated using the OligoAnalyzer 3.1, as described by Schroeder et al. [55] and Yan et al. [20]. The primers were synthesized by Eurofin MWG Operon LLC (Huntsville, AL, USA). The performance of the designed primer set in PCR amplification was then evaluated at different annealing temperatures $\left(56,58\right.$, and $\left.60^{\circ} \mathrm{C}\right)$ using DNA from P. dakotaensis, along with DNA from P. neglectus, P. penetrans, P. scribneri, and P. thornei. Subsequently, $58^{\circ} \mathrm{C}$ was determined to be the optimal annealing temperature at which the primer pair performed the best.

\subsection{Detection Specificity of the Primers in PCR}

The designed primer set was further evaluated for detection specificity through conventional and real-time PCR using DNA from multiple populations of the target species (P. dakotaensis) and multiple populations of five other confirmed species of Pratylenchus (Table 2). They included two populations of P. scribneri and P. neglectus, and one population of P. thornei, P. penetrans, and another newly identified Pratylenchus sp. (Table 2, sample ID: $\mathrm{Hg}$ 51). Additionally, DNA from eight populations of plant-parasitic nematodes in other genera, including Paratylenchus sp., Paratrichodorus sp., Tylenchorhynchus sp., Helicotylenchus sp., Heterodera glycines, H. schatii, Hoplolaimus sp., and Xiphinema sp., were used in the 
specificity test. Furthermore, DNA from two genera of non-plant-parasitic nematodes were also used in the specificity test (Table 2, sample ID: NPN1 and NPN2). For each nematode population used in the specificity testing, three independent DNA extractions were conducted and used as biological replicates.

\subsection{Conventional PCR Assay}

The presence and quality of the template in DNA extracts used in this study were verified using conventional PCR amplification of the ITS1 rDNA with the universal primer set rDNA2/rDNA1.58s [62]. The PCR amplification conditions were initial denaturing at $94{ }^{\circ} \mathrm{C}$ for $3 \mathrm{~min}$ followed by 40 cycles of denaturing at $94{ }^{\circ} \mathrm{C}$ for $45 \mathrm{~s}$, annealing at $55^{\circ} \mathrm{C}$ for $1 \mathrm{~min}$, and extension at $72{ }^{\circ} \mathrm{C}$ for $1 \mathrm{~min}$; with a final extension at $72{ }^{\circ} \mathrm{C}$ for $10 \mathrm{~min}$, as suggested by Cherry et al. [62]. The Bio-Rad T100 thermal cycler (Hercules, CA, USA) was used to conduct all conventional PCR amplification reactions for this study. For the newly designed primer set, IC-ITS1F/IC-ITS1R, the species-specific conventional PCR reaction mixture $(20 \mu \mathrm{L})$ consisted of $1.5 \mu \mathrm{L}$ of DNA template, $0.5 \mu \mathrm{M}$ forward and reverse primers, $0.2 \mathrm{mM}$ dNTP, $1.5 \mathrm{mM} \mathrm{MgCl} 2$, 1 X Green GoTaq Flexi buffer, 1 unit of GoTaq Flexi DNA polymerase (Promega Corp., Madison. WI, USA), and $11.2 \mu \mathrm{L}$ of double-distilled water. The amplification conditions for the designed primer set were initial denaturation at $94{ }^{\circ} \mathrm{C}$ for $3 \mathrm{~min}$ followed by 35 cycles of denaturing at $94{ }^{\circ} \mathrm{C}$ for $40 \mathrm{~s}$, annealing at $58{ }^{\circ} \mathrm{C}$ for $50 \mathrm{~s}$, extension at $72{ }^{\circ} \mathrm{C}$ for $1 \mathrm{~min}$, and a final extension for $10 \mathrm{~min}$ at $72{ }^{\circ} \mathrm{C}$. After DNA amplification, $8 \mu \mathrm{L}$ of the PCR products were added to the wells of a $2 \%$ agarose gel stained with ethidium bromide. The PCR products in the gel were then separated by gel electrophoresis for $30 \mathrm{~min}$ at $90 \mathrm{~V}$. The banding pattern of the PCR products was visualized under UV light and photographed using the AlphaImager Gel Documentation system (Proteinsimple Inc., Santa Clara, CA, USA). For each sample, conventional PCR reactions were conducted with three biological replicates.

\subsection{Real-Time PCR Assay}

To determine whether the IC-ITS1F/IC-ITS1R primer set can be used in real-time PCR assay for the identification of P. dakotaensis, a SYBR-based real-time PCR assay was conducted. In the real-time PCR assay, a $12 \mu \mathrm{L}$ qPCR reaction mixture contained $1.5 \mu \mathrm{L}$ of DNA template, $6 \mu \mathrm{L}$ of SsoAdvanced Universal SYBR Green Supermix (Bio-Rad), $0.5 \mu \mathrm{L}$ of each forward and reverse primer $(10 \mu \mathrm{M})$, and $3.5 \mu \mathrm{L}$ of nuclease-free PCR grade water. In each experiment, non-template controls containing nuclease-free PCR grade water in place of DNA were included. The real-time PCR amplification was performed using the Bio-Rad CFX96 Touch Real-time PCR detection system (Bio-Rad Laboratories, Inc., Hercules, CA, USA.). The cycling conditions for the real-time PCR amplification were incubation at $95^{\circ} \mathrm{C}$ for $4 \mathrm{~min}$ followed by 35 cycles of $95^{\circ} \mathrm{C}$ for $10 \mathrm{~s}$ and $58{ }^{\circ} \mathrm{C}$ for $30 \mathrm{~s}$. A melting curve temperature profile was generated by increasing the temperature of the reaction from 65 to $95^{\circ} \mathrm{C}$ with a ramp rate of $0.5^{\circ} \mathrm{C} \mathrm{s}^{-1}$ to evaluate the amplification specificity. Each reaction was run in triplicate as technical replicates and three independent biological replicates were assessed for each sample, thus generating nine observations per sample in real-time PCR. The Bio-Rad CFX Manager Software (V3.1) was used to analyze the real-time PCR data, and the quantification cycle value $(\mathrm{Cq})$ for each reaction was determined at default settings. The real-time PCR product quality was also evaluated by electrophoresis on a $2 \%$ agarose gel as described above.

\subsection{Detection Sensitivity of PCR Assays}

The sensitivity of the assays was investigated to establish a detection limit for the conventional and real-time PCR assays. The sensitivity, which refers to the minimum number of target nematode individuals that could produce visible amplicons in the gel electrophoresis portion of the conventional PCR assay or generate a Cq value lower than 34 in the real-time PCR assay [17,30], was evaluated using a sequential two-fold serial dilution of DNA extracted from four individuals of $P$. dakotaensis. Thus, DNA extracted 
from four $P$. dakotaensis individuals were diluted nine times down to $1 / 64$ equivalent of a single nematode $(4,2,1,1 / 2,1 / 4,1 / 8,1 / 16,1 / 32$, and $1 / 64)$. In a real-time PCR assay, each sequential dilution from three independent DNA extracts was then used as biological replicates and the PCR assay was conducted in triplicate as technical replicates. This resulted in nine observations for each dilution level in real-time PCR. The Cq values from each dilution level were then plotted against the corresponding log 10 of equivalent numbers of $P$. dakotaensis individuals to generate a standard curve, from which the coefficient of determination $\left(R^{2}\right)$ was determined and amplification efficiency was calculated using the equation, $\mathrm{E}=10^{(1 /-\mathrm{m})}-1$, where $\mathrm{m}$ is the slope of the equation. The same DNA templates from the sequential serial dilution of the first biological replicate were used to determine the detection limit for the conventional PCR assay.

\subsection{Isolation, Identification, and Verification of Root-Lesion Nematode Species Collected from Soybean Fields}

During 2019, 20 soil samples were collected from North Dakota soybean fields, or fields with a history of soybean production that were suspected to be infested with Pratylenchus spp. based on our previous research. One of these 20 soil samples was collected from a soybean field neighboring the field in which P. dakotaensis was first discovered. Additionally, in 2019, a soil sample was also collected from the field in which P. dakotaensis was first discovered. Nematodes from these samples were extracted and used to test whether the PCR assays could accurately detect and differentiate P. dakotaensis from other species of Pratylenchus (Table 3). In each field, sampling was conducted in a zig-zag pattern starting $76 \mathrm{~m}$ (100 paces) away from the field entrance, by collecting soil from 20-25 sampling points using a $2.5 \mathrm{~cm}$ diameter soil probe from depths of $1-30 \mathrm{~cm}$ below the soil surface [63]. After compositing and thoroughly mixing the soil samples collected from each field, nematodes were extracted from a $100 \mathrm{~cm}^{3}$ subsample using the sugar centrifugal-floatation method [58], as described previously. Nematodes belonging to the genus Pratylenchus were identified and enumerated based on morphological features using a compound microscope (100× magnification) and the density of Pratylenchus sp. in the $100 \mathrm{~cm}^{3}$ soil subsample was calculated. Individuals of Pratylenchus sp. were then isolated from each sample using a dental pick, and DNA was extracted using the Proteinase K method [31], as described previously. For each sample, single nematode DNA extractions were conducted independently from three different individuals of Pratylenchus as three biological replicates. The presence of DNA was confirmed using PCR with the universal primer set rDNA2/rDNA1.58s, as described by Cherry et al. [62]. Conventional species-specific PCR was then conducted to identify the Pratylenchus sp. in each sample. The primers used in species-specific PCR included PsF7/PsR7 [17], PNEG-F1/D3B5 [22], PTHO/D3B [22], and PP5F/PP5R [23], which are specific to P. scribneri, P. neglectus, P. thornei, and P. penetrans, respectively. The amplification conditions for the species-specific PCR followed the corresponding authors' recommendations. Moreover, each DNA sample was tested in the conventional and real-time PCR assays with the newly designed primer set IC-ITS1F/ITS1R to confirm the specificity of the new PCR assays. The banding pattern of the PCR products in the conventional PCR assay and the Cq values from the real-time PCR assay were then recorded. Samples that were identified as P. dakotaensis through PCR assays with the IC-ITS1F/IC-ITS1R primer set were further validated through direct DNA sequencing by following the procedure described in Section 4.3.

Author Contributions: Conceptualization, G.Y.; methodology, G.Y. and I.A.C.; software, I.A.C. and G.Y.; validation, I.A.C.; formal analysis, I.A.C. and G.Y.; investigation, I.A.C. and G.Y.; resources, G.Y.; data curation, I.A.C. and G.Y.; writing—original draft preparation, I.A.C.; writing-review and editing, G.Y.; visualization, I.A.C.; supervision, G.Y.; project administration, G.Y.; funding acquisition, G.Y. All authors have read and agreed to the published version of the manuscript.

Funding: This research was funded by North Dakota Soybean Council.

Institutional Review Board Statement: Not applicable. 
Informed Consent Statement: Not applicable.

Data Availability Statement: All data generated or analyzed during this study are included in this article.

Acknowledgments: We thank North Dakota Soybean Council and North Dakota State Board of Agricultural Research and Education for funding this project. The authors are grateful to Danqiong Huang for her valuable suggestions and guidance during the development process of the PCR assays. The authors would also like to thank North Dakota State University Nematology Lab members for their assistance in collecting soil samples from soybean fields. Additionally, the authors would like to thank North Dakota soybean growers for allowing us to collect soil samples from their fields.

Conflicts of Interest: The authors declare no conflict of interest. The funders had no role in the design of the study; in the collection, analyses, or interpretation of data; in the writing of the manuscript, or in the decision to publish the results.

\section{References}

1. Sasser, J.N.; Freckman, D.W. A world perspective on nematology: The role of the society. In Vistas on Nematology: A Commemoration of the Twenty-Fifth Anniversary of the Society of Nematologists, 1st ed.; Veech, J.A., Dickerson, D.W., Eds.; Society of Nematologists: Lakeland, FL, USA, 1987; pp. 7-14.

2. Castillo, P.; Vovlas, N. Pratylenchus (Nematoda: Pratylenchidae): Diagnosis, biology, pathogenicity and management. Nematol. Monogr. Perspect. 2007, 6, 1-543. [CrossRef]

3. Jones, J.T.; Haegeman, A.; Danchin, E.G.J.; Gaur, H.S.; Helder, J.; Jones, M.G.K.; Kikuchi, T.; Manzanilla-López, R.; PalomaresRius, J.E.; Wesemael, W.M.L.; et al. Top 10 plant-parasitic nematodes in molecular plant pathology. Mol. Plant Pathol. 2013, 14, 946-961. [CrossRef]

4. Davis, E.L.; MacGuidwin, A.E. Lesion nematode disease. Plant Health Instr. 2000. [CrossRef]

5. Taylor, S.P.; Vanstone, V.A.; Ware, A.H.; McKay, A.C.; Szot, D.; Russ, M.H. Measuring yield loss in cereals caused by root-lesion nematodes (Pratylenchus Neglectus and P. Thornei) with and without nematicide. Aust. J. Agric. Res. 1999, 50, 617-622. [CrossRef]

6. Smiley, R.W.; Whittaker, R.G.; Gourlie, J.A.; Easley, S.A. Suppression of wheat growth and yield by Pratylenchus neglectus in the Pacific Northwest. Plant Dis. 2005, 89, 958-968. [CrossRef]

7. Holgado, R.; Skau, K.A.O.; Magnusson, C. Field damage in potato by lesion nematode Pratylenchus penetrans, its association with tuber symptoms and its survival in storage. Nematol. Medit. 2009, 37, 25-29.

8. Lima, F.D.O.; dos Santos, G.R.; Nogueira, S.R.; dos Santos, P.R.R.; Correa, V.R. Population dynamics of the root-lesion nematode, Pratylenchus brachyurus, in soybean fields in Tocantins state and its effect to soybean yield. Nematropica 2015, 45, 170-177.

9. Thompson, J.P.; Owen, K.J.; Stirling, G.R.; Bell, M.J. Root-lesion nematodes (Pratylenchus Thornei and P. Neglectus): A review of recent progress in managing a significant pest of grain crops in Northern Australia. Aust. Plant Pathol. 2008, 37, $235-242$. [CrossRef]

10. Handoo, Z.A.; Golden, A.M. A key and diagnostic compendium to the species of the genus Pratylenchus Filipjev, 1936 (lesion nematodes). J. Nematol. 1989, 21, 202-218. [PubMed]

11. Kimpinski, J. Root-lesion nematodes in potatoes. Am. Potato J. 1979, 56, 79-86. [CrossRef]

12. Luc, M. A reappraisal of Tylenchina (Nemata). 7. The family Pratylenchidae Thorne, 1949. Annu. Rev. Nematol. 1987, 10, 203-218.

13. Wheeler, T.A.; Madden, L.V.; Rowe, R.C.; Riedel, R.M. Modeling of yield loss in potato early dying caused by Pratylenchus penetrans and Verticillium Dahliae. J. Nematol. 1992, 24, 99-102. [PubMed]

14. Pinochet, P.; Cenis, J.L.; Fernández, C.; Doucet, M.; Maruli, J. Reproductive fitness and random amplified polymorphic DNA variation among isolates of Pratylenchus vulnus. J. Nematol. 1994, 26, 271-277. [PubMed]

15. Al-Banna, L.; Ploeg, A.T.; Williamson, V.M.; Kaloshian, I. Discrimination of six Pratylenchus species using PCR and species-specific primers. J. Nematol. 2004, 36, 142-146. [CrossRef]

16. Baidoo, R.; Yan, G.; Nagachandrabose, S.; Skantar, A.M. Developing a real-time PCR assay for direct identification and quantification of Pratylenchus penetrans in soil. Plant Dis. 2017, 101, 1432-1441. [CrossRef] [PubMed]

17. Huang, D.; Yan, G.P. Specific detection of the root-lesion nematode Pratylenchus scribneri using conventional and real-time PCR. Plant Dis. 2017, 101, 359-365. [CrossRef]

18. Oliveira, C.M.G.; Blok, V.; Neilson, R.; Mróz, T.; Roberts, D. Hydrolysis probe-based PCR for detection of Pratylenchus crenatus, P. neglectus and P. penetrans. Nematology 2017, 19, 81-91. [CrossRef]

19. Uehara, T.; Mizukubo, T.; Kushida, A.; Momota, Y. Identification of Pratylenchus penetrans (Cobb) by PCR using ITS-based species-specific primers. Jpn. J. Nematol. 1998, 28, 1-7. [CrossRef]

20. Yan, G.P.; Smiley, R.W.; Okubara, P.A. Detection and quantification of Pratylenchus thornei in DNA extracted from soil using real-time PCR. Phytopathology 2012, 102, 14-22. [CrossRef]

21. Yan, G.P.; Smiley, R.W.; Okubara, P.A.; Skantar, A.M.; Reardon, C.L. Developing a real-time PCR assay for detection and quantification of Pratylenchus neglectus in soil. Plant Dis. 2013, 97, 757-764. [CrossRef] 
22. Yan, G.P.; Smiley, R.W.; Okubara, P.A.; Skantar, A.; Easley, S.A.; Sheedy, J.G.; Thompson, A.L. Detection and discrimination of Pratylenchus neglectus and P. thornei in DNA extracts from soil. Plant Dis. 2008, 92, 1480-1487. [CrossRef]

23. Mekete, T.; Reynolds, K.; Lopez-Nicora, H.D.; Gray, M.E.; Niblack, T.L. Distribution and diversity of root-lesion nematode (Pratylenchus Spp.) associated with Miscanthus $\times$ Giganteus and Panicum virgatum used for biofuels, and species identification in a multiplex polymerase chain reaction. Nematology 2011, 13, 673-686. [CrossRef]

24. Wittwer, C.T.; Herrmann, M.G.; Moss, A.A.; Rasmussen, R.P. Continuous fluorescence monitoring of rapid cycle DNA amplification. BioTechniques 1997, 22, 130-138. [CrossRef] [PubMed]

25. Arora, D.; Yan, G.P.; Baidoo, R. Developing a real-time PCR assay for direct detection and quantification of Pratylenchus scribneri in field soil. Nematology 2020, 22, 733-744. [CrossRef]

26. Berry, S.D.; Fargette, M.; Spaull, V.W.; Morand, S.; Cadet, P. Detection and quantification of root-knot nematode (Meloidogyne Javanica), lesion nematode (Pratylenchus zeae) and dagger nematode (Xiphinema elongatum) parasites of sugarcane using real-time PCR. Mol. Cell. Probes 2008, 22, 168-176. [CrossRef]

27. Machado, A.C.Z.; Ferraz, L.C.C.B.; de Oliveira, C.M.G. Development of a species-specific reverse primer for the molecular diagnostic of Pratylenchus brachyurus. Nematropica 2007, 37, 249-257.

28. Yan, G.P.; Plaisance, A.; Huang, D.; Chowdhury, I.A.; Handoo, Z.A. First report of the new root-lesion nematode Pratylenchus sp. on soybean in North Dakota. Plant Dis. 2017, 101, 1554. [CrossRef]

29. Handoo, Z.A.; Yan, G.P.; Kantor, M.R.; Huang, D.; Chowdhury, I.A.; Plaisance, A.; Bauchan, G.R.; Mowery, J.D. Morphological and molecular characterization of Pratylenchus dakotaensis n. Sp. (Nematoda: Pratylenchidae), a new root-lesion nematode species on soybean in North Dakota, USA. Plants 2021, 10, 168. [CrossRef]

30. Huang, D.; Yan, G.P.; Skantar, A.M. Development of real-time and conventional PCR assays for identifying stubby root nematode Paratrichodorus Allius. Plant Dis. 2017, 101, 964-972. [CrossRef]

31. Kumari, S.; Subbotin, S.A. Molecular characterization and diagnostics of stubby root and virus vector nematodes of the family Trichodoridae (Nematoda: Triplonchida) using ribosomal RNA Genes. Plant Pathol. 2012, 61, 1021-1031. [CrossRef]

32. Mai, W.F.; Mullin, P.G.; Lyon, H.H.; Loeffler, K. Plant-Parasitic Nematodes: A Pictorial Key to Genera, 5th ed.; Cornell University Press: Ithaca, NY, USA, 1996; pp. 10-277.

33. Schmitt, D.P.; Barker, K.R. Damage and reproductive potentials of Pratylenchus brachyurus and P. Penetrans on Soybean. J. Nematol. 1981, 13, 327-332.

34. Koenning, S.R.; Overstreet, C.; Noling, J.W.; Donald, P.A.; Becker, J.O.; Fortnum, B.A. Survey of crop losses in response to phytoparasitic nematodes in the United States for 1994. J. Nematol. 1999, 31, 587-618. [PubMed]

35. Schrader, C.; Schielke, A.; Ellerbroek, L.; Johne, R. PCR inhibitors-occurrence, properties and removal. J. Appl. Microbiol. 2012, 113, 1014-1026. [CrossRef] [PubMed]

36. De Weerdt, M.; Kox, L.; Waeyenberge, L.; Viaene, N.; Zijlstra, C. A real-time PCR assay to identify Meloidogyne minor. J. Phytopathol. 2011, 3, 30-37. [CrossRef]

37. Huang, D.; Yan, G.P.; Gudmestad, N.; Skantar, A. Quantification of Paratrichodorus allius in DNA extracted from soil using TaqMan Probe and SYBR Green real-time PCR assays. Nematology 2017, 19, 987-1001. [CrossRef]

38. Huang, D.; Yan, G.P.; Gudmestad, N.; Whitworth, J.; Frost, K.; Brown, C.; Ye, W.; Agudelo, P.; Crow, W. Molecular characterization and identification of stubby root nematode species from multiple states in the United States. Plant Dis. 2018, 102, 2101-2111. [CrossRef] [PubMed]

39. Huang, D.; Yan, G.P.; Gudmestad, N.; Ye, W.; Whitworth, J.; Frost, K.; Crow, W.; Hajihassani, A. Developing a one-step multiplex PCR assay for rapid detection of four stubby-root nematode species, Paratrichodorus allius, P. minor, P. porosus, and Trichodorus obtusus. Plant Dis. 2019, 103, 404-410. [CrossRef]

40. Li, W.; Yan, Z.; Nakhla, M.K.; Skantar, A.M. Real-time PCR for detection and identification of Anguina funesta, A. agrostis, A. tritici, and A. pacificae. Plant Dis. 2015, 99, 1584-1589. [CrossRef] [PubMed]

41. Subbotin, S.A.; Madani, M.; Krall, E.; Sturhan, D.; Moens, M. Molecular diagnostics, taxonomy, and phylogeny of the stem nematode Ditylenchus dipsaci species complex based on the sequences of the internal transcribed spacer-rDNA. Phytopathology 2005, 95, 1308-1315. [CrossRef]

42. de Luca, F.; Reyes, A.; Troccoli, A.; Castillo, P. Molecular variability and phylogenetic relationships among different species and populations of Pratylenchus (Nematoda: Pratylenchidae) as inferred from the analysis of the ITS rDNA. Eur. J. Plant Pathol. 2011, 130, 415-426. [CrossRef]

43. Subbotin, S.A.; Moens, M. Molecular taxonomy and phylogeny. In Plant Nematology, 2nd ed.; Perry, R.N., Moens, M., Eds.; CABI: Wallingford, UK, 2006; pp. 33-58.

44. Blouin, M.S. Molecular prospecting for cryptic species of nematodes: Mitochondrial DNA versus internal transcribed spacer. Int. J. Parasitol. 2002, 32, 527-531. [CrossRef]

45. Gorny, A.M.; Wang, X.; Hay, F.S.; Pethybridge, S.J. Development of a species-specific PCR for detection and quantification of Meloidogyne hapla in soil using the 16D10 root-knot nematode effector gene. Plant Dis. 2019, 103, 1902-1909. [CrossRef]

46. Seesao, Y.; Gay, M.; Merlin, S.; Viscogliosi, E.; Aliouat-Denis, C.M.; Audebert, C. A review of methods for nematode identification. J. Microbiol. Meth. 2017, 138, 37-49. [CrossRef] 
47. Valentini, A.; Mattiucci, S.; Bondanelli, P.; Webb, S.C.; Mignucci-Giannone, A.A.; Colom-Llavina, M.M.; Nascetti, G. Genetic relationships among Anisakis species (Nematoda: Anisakidae) inferred from mitochondrial cox2 sequences, and comparison with allozyme data. J. Parasitol. 2006, 92, 156-166. [CrossRef] [PubMed]

48. Yu, H.; Chronis, D.; Lu, S.; Wang, X. Chorismate Mutase: An alternatively spliced parasitism gene and a diagnostic marker for three important Globodera nematode species. Eur. J. Plant Pathol. 2011, 129, 89-102. [CrossRef]

49. Dieffenbach, C.W.; Lowe, T.M.J.; Dveksler, G.S. General concepts for PCR primer design. PCR Methods Appl. 1993, 3, 30-37. [CrossRef]

50. Singh, V.K.; Kumar, A. Primer design. Mol. Biol. Today 2001, 2, 27-32.

51. Rychlik, W.; Spencer, W.J.; Rhoads, R.E. Optimization of the annealing temperature for DNA amplification in vitro. Nucleic Acids Res. 1990, 18, 6409-6412. [CrossRef]

52. Erlich, H.A.; Gelfand, D.; Sninsky, J.J. Recent advances in the polymerase chain reaction. Science 1991, 252, 1643-1651. [CrossRef] [PubMed]

53. Delcourt, S.; Vernière, C.; Boyer, C.; Pruvost, O.; Hostachy, B.; Robène-Soustrade, I. Revisiting the specificity of PCR primers for diagnostics of Xanthomonas citri Pv. citri by experimental and in silico analyses. Plant Dis. 2013, 97, 373-378. [CrossRef]

54. Okubara, P.A.; Schroeder, K.L.; Paulitz, T.C. Identification and quantification of Rhizoctonia solani and R. oryzae using real-time polymerase chain reaction. Phytopathology 2008, 98, 837-847. [CrossRef] [PubMed]

55. Schroeder, K.L.; Okubara, P.A.; Tambong, J.T.; Lévesque, C.A.; Paulitz, T.C. Identification and quantification of pathogenic Pythium Spp. from soils in eastern washington using real-time polymerase chain reaction. Phytopathology 2006, 96, 637-647. [CrossRef] [PubMed]

56. Jeszke, A.; Dobosz, R.; Obrepalska-Steplowska, A. A fast and sensitive method for the simultaneous identification of three important nematode species of the genus Ditylenchus. Pest Manag. Sci. 2015, 71, 243-249. [CrossRef]

57. Mokrini, F.; Waeyenberge, L.; Viaene, N.; Abbad Andaloussi, F.; Moens, M. Quantitative detection of the root-lesion nematode, Pratylenchus penetrans, using qPCR. Eur. J. Plant Pathol. 2013, 137, 403-413. [CrossRef]

58. Jenkins, W.R. A Rapid centrifugal-flotation technique for separating nematodes from soil. Plant Dis. Rep. 1964, $48,692$.

59. Subbotin, S.A.; Ragsdale, E.J.; Mullens, T.; Roberts, P.A.; Mundo-Ocampo, M.; Baldwin, J.G. A phylogenetic framework for root-lesion nematodes of the genus Pratylenchus (Nematoda): Evidence from 18S and D2-D3 expansion segments of 28S ribosomal RNA genes and morphological characters. Mol. Phylogenet. Evol. 2008, 48, 491-505. [CrossRef] [PubMed]

60. Vrain, T.C.; Wakarchuk, D.A.; Lévesque, A.C.; Hamilton, R.I. Intraspecific rDNA restriction fragment length polymorphism in the Xiphinema americanum group. Fundam. Appl. Nemalol. 1992, 15, 563-573.

61. Hall, T.A. BioEdit: A user-friendly biological sequence alignment editor and analysis Program for Windows 95/98/NT. Nucliec Acids Symp. Ser. 1999, 41, 95-98.

62. Cherry, T.; Szalanski, A.L.; Todd, T.C.; Powers, T.O. The internal transcribed spacer region of belonolaimus (Nemata: Belonolaimidae). J. Nematol. 1997, 29, 23-29.

63. Chowdhury, I.A.; Yan, G.P.; Friskop, A. Occurrence of vermiform plant-parasitic nematodes in North Dakota corn fields and impact of environmental and soil factors. Can. J. Plant Pathol. 2020, 42, 429-444. [CrossRef] 